\title{
POLITYKA KLIMATYCZNO-ENERGETYCZNA KLUCZOWA BARIERĄ ROZWOJU ZRÓWNOWAŻONEGO W POLSCE
}

\begin{abstract}
Streszczenie
Promocja rozwoju zrównoważonego opartego na trwałości klimatycznej jako koncepcji prowadzącej do dekarbonizacji gospodarki w strategii „Europa 2020” i restrykcyjnym pakiecie zimowym obejmującym perspektywę 2030 roku oraz w najnowszych regulacjach BAT stanowi wielkie wyzwanie dla Polski zarówno ze względu na wyjściową strukturę bilansu energetycznego i charakterystykę systemów energetycznych, jak i na wysokie koszty dla gospodarki i społeczeństwa. W perspektywie do 2030 roku dostosowanie źródeł energii i modernizacja infrastruktury energetycznej jest najważniejszą barierą w drodze do rozwoju zrównoważonego. W modernizacji energetyki kluczowe są: substytucja węgla z gazem, rozwój OZE, poprawa efektywności energetycznej i gospodarka skojarzona. Poza tym, nie ma wielu wydajnych rozwiązań technicznych, które by z jednej strony „ratowały” klimat i wiodły do gospodarki niskoemisyjnej, $z$ drugiej zaś zapewniałyby minimalne perspektywy węgla. Możliwości redukcji $\mathrm{CO}_{2} \mathrm{w}$ procesach spalania węgla są ograniczone, natomiast umiarkowane szanse można wiązać z procesami jego konwersji. Średniookresowy bilans kosztów i korzyści modernizacji energetyki wydaje się niekorzystny, jednak skuteczna transformacja energetyki i innowacje mogą uchronić polska gospodarkę i społeczeństwo przed jeszcze wyższymi kosztami w przyszłości.
\end{abstract}

Słowa kluczowe: trwałość klimatyczna, dekarbonizacja, gospodarka niskoemisyjna, elektroenergetyka, ciepłownictwo i ogrzewnictwo, innowacje, polityka publiczna, zarządzanie energia

\section{CLIMATE-ENERGY POLICY AS CRUCIAL BARRIER TO SUSTAINABLE DEVELOPMENT IN POLAND}

\begin{abstract}
Summary
The paper explains the meaning of climate sustainability and the way in which the category of sustainable development as a concept of total decarbonization is understood in the UE. The author shows that the strategy Europe 2020 and the latest winter package for the period until 2030 - the most recent regulations of BAT - pose a serious challenge to the Polish economy and society because of its structure of energy balance and high costs for the economy and society. The paper discusses the possibilities and barriers of technological change in the broadly understood energy sector that can lead to the decarbonization and low emission economy, but at the same time be feasible and economically acceptable. Apart from replacing coal with gas, renewables, energy efficiency, and cogeneration, there exist several efficient technologies that would protect the climate and be consistent with the low emission economy, ensuring
\end{abstract}


at the same time minimum prospects for coal. Especially the possibilities of $\mathrm{CO}_{2}$ reductions in the process of coal combustion are very limited, but moderate success can be expected from conversion of coal to gaseous and solid forms. The medium-term balance of costs and benefits of modernising the energy sector seems unfavourable, but an effective transformation and innovations can spare the Polish economy and society higher costs in the future.

Key words: climate sustainability, decarbonization, low emission economy, electric power industry, heating sector, innovations, public policy, energy management

JEL classification: Q01, Q40, Q55, Q57

\section{Wstęp}

Trwałość klimatyczna i wynikające z niej rozumienie rozwoju zrównoważonego jako koncepcji walki ze zmianami klimatycznymi i konsekwentnej dekarbonizacji gospodarki jest istota polityki społeczno-gospodarczej oraz różnych strategii Unii Europejskiej ostatnich dwóch dekad. Promocja rozwoju zrównoważonego opartego na trwałości klimatycznej, ujmowanego w strategii „Europa 2020” oraz w planach Unii Europejskiej do 2030 roku i dalszej perspektywie, obiektywnie stanowi wielkie wyzwanie dla Polski zarówno ze względu na jednostronną strukturę bilansu energetycznego i pochodną od tego charakterystykę systemów energetycznych, jak i na koszty wymuszonych kierunków rozwoju energetyki. Realizacja wymogów polityki klimatyczno-energetycznej Unii Europejskiej jest zasadniczą $i$ trudną do przełamania barierą rozwoju zrównoważonego. Na tym tle pojawia się pytanie, czy Polska jest w stanie ukierunkować rozwój społeczno-gospodarczy w zgodzie z wymogami Unii Europejskiej, a w szczególności osiagnąć cele związane z ograniczeniem emisji $\mathrm{CO}_{2}$ i zakresem gospodarki węglowej. W tym kontekście ważne stają się realne rozwiązania o charakterze: technicznym, organizacyjnym i zarządczym, które znacząco mogą przyczynić się do mitygacji zmian klimatycznych i rozwoju gospodarki niskoemisyjnej w: elektroenergetyce, ciepłownictwie i ogrzewnictwie.

Celem opracowania jest wskazanie skutków społeczno-gospodarczych dla Polski, wynikających z implementacji polityki klimatyczno-energetycznej Unii Europejskiej. Dalszym celem jest próba określenia możliwości i rozwiązań przybliżających Polskę do osiagnięcia wysokich wymagań klimatycznych i emisyjnych w: elektroenergetyce, ciepłownictwie i ogrzewnictwie oraz w transporcie, z zarysowaniem głównych problemów rozwoju tych dziedzin. Chodzi tu o ukazanie zmian: strukturalnych, technicznych i współbieżnych z wymogami polityki klimatyczno-energetycznej Unii Europejskiej, a także wnoszących realny wkład w dekarbonizację i gospodarkę niskoemisyjną w Polsce.

\section{Rozwój zrównoważony w warunkach trwałości klimatycznej}

Koncepcja rozwoju zrównoważonego wypracowana przez dyscypliny ekonomii heterodoksyjnej, a zwłaszcza przez ekonomię ekologiczna, opierała się na kategorii trwałości mocnej. Rozwój zrównoważony, uwzględniający trwałość mocną jawił się jako zadanie ambitne i trudne do realizacji dla społeczności globalnej. W przeciwieństwie do 
heterodoksji, mainstreamowa ekonomia środowiska opowiadała się za mniejszymi: ambicjami, realizmem i praktyczną wykonalnościa, preferując trwałość słabą ${ }^{1}$. Jednakże współczesne definiowanie i rozumienie kategorii rozwoju zrównoważonego w ostatnich dwóch dekadach zostało zmienione na skutek uznania katastroficznych opinii części klimatologów. Tradycyjne podejście heterodoksji w precyzowaniu trwałości zostało wyparte przez ekonomię globalnego ocieplenia. W trwałości klimatycznej (climate sustainability) przed tradycyjne obszary problemowe rozwoju zrównoważonego, takie jak: zanieczyszczenie powietrza trującymi substancjami, odpady, transport, gospodarka materiałowa, energia, woda i ścieki, żywność, gospodarka przestrzenna i bioróżnorodność, kultura i dziedzictwo kulturowe, sprawiedliwość, zatrudnienie, gospodarka oraz zdrowie, na pierwsze miejsce wysunęła się ochrona klimatu i gospodarka niskowęglowa, oznaczająca de facto dekarbonizację gospodarki². Bez wattpienia, trwałość klimatyczna jest wielkim wyzwaniem dla współczesnego pokolenia, ponieważ ambitnie podnosi poprzeczkę przez dodanie celów klimatycznych; jest to zatem naprawdę trwałość mocna.

Zmodyfikowane rozumienie rozwoju zrównoważonego występuje w podstawowych dokumentach Unii Europejskiej, a w szczególności odnoszących się do polityki klimatyczno-energetycznej, takich jak obecnie obowiązująca strategia „Europa 2020” oraz zarys strategii klimatyczno-energetycznej 2030 i dalsze plany na perspektywę 2050. W strategiach kluczowe miejsce zajmują cele klimatyczne i walka z paliwami kopalnymi, głównie $z$ węglem. Zakwestionowanie trwałości paliw kopalnych jest podejściem wyprzedzającym globalne porozumienie klimatyczne o realnym, nieblankietowym znaczeniu. Wręcz przeciwnie, zbyt ambitna walka Unii Europejskiej z $\mathrm{CO}_{2}$ jest szkodliwa dla klimatu, ze względu na migrację europejskiego przemysłu energochłonnego do USA i gospodarek wschodzących.

Cele dotychczasowej strategii „Europa 2020” w zakresie: redukcji $\mathrm{CO}_{2}$, udziału energii odnawialnej i efektywności energetycznej (20/20/20) zostały podwyższone w propozycjach obejmujących perspektywę 2030 roku. Zasadnicze elementy tej nowej strategii, ujętej w opracowaniu Komisji Europejskiej A policy framework for climate and energy in the period from 2020 to 2030, przedstawiały się następująco: obniżenie o 40\% emisji $\mathrm{CO}_{2}$ na poziomie całej Unii Europejskiej, osiagnięcie co najmniej 27-procentowgo udziału OZE w bilansie energetycznym na poziomie całej Unii Europejskiej, osiagnięcie poprawy efektywności energetycznej, odniesienie do bezpieczeństwa dostaw energii i konkurencyjności, reforma EU ETS oraz nowy system współrządzenia [A policy..., 2014, s. 5-8]. Na szczycie Unii Europejskiej w październiku 2014 roku w pakiecie 2.0 przyjęto wiążący cel klimatyczny oznaczający obniżenie emisji $\mathrm{CO}_{2}$ co najmniej o 40\% od 1990 roku (ETS - 43\% od 2005 roku i non-ETS - 30\% od 2005 roku) oraz niewiążące cele klimatyczne (OZE - 27\% i efektywność energetyczna - 27\%). Ponadto, wprowadzono

1 Trwałość mocna oznacza konieczność zachowania istniejących aktywów naturalnych zawartych w tzw. krytycznym kapitale naturalnym (strong sustainability), natomiast trwałość słaba oznacza zachowanie stałości sumy: kapitału wytworzonego przez człowieka, kapitału ludzkiego i kapitału naturalnego (weak sustainability) [Jeżowski, 2013, s. 121-13].

2 Trwałość klimatyczna oznacza, że obok zachowania krytycznego kapitału naturalnego, przyjmuje się dążenie do zahamowania niekorzystnych zmian klimatu, czemu głównie ma służyć ograniczenie emisji gazów cieplarnianych [Jeżowski, 2017, s. 47]. 
mechanizm ręcznego sterownia EU ETS (back-loading) i darmowe uprawnienia emisyjne $\mathrm{CO}_{2}$ dla biedniejszych państw członkowskich po 2020 roku, bez rozstrzygnięcia, jakie będa warunki uzyskania darmowych uprawnień emisyjnych [European Council..., 2014, s. 3-6]. Ostateczne ustalenia na następną dekadę określa tzw. pakiet zimowy, obszerny dokument pod nazwa „Czysta energia dla wszystkich Europejczyków”, opublikowany przez Komisję Europejską 30 listopada 2016 roku. Stanowi on uzupełnienie konkluzji Rady Europejskiej i Komisji Europejskiej z lat 2014-2015. Pakiet zimowy wprowadza dopuszczalność źródeł energii elektrycznej w rynku mocy o emisyjności $\mathrm{CO}_{2}$ niższej niż $550 \mathrm{~kg} / \mathrm{MWh}$. Praktycznie, wskaźnik ten eliminuje wszystkie elektrownie węglowe, uniemożliwiając państwom członkowskim swobodny wybór miksu energetycznego [Morawiecka, 2017]. Pakiet zimowy silnie uderza w polską energetykę - to z jednej strony cios skierowany w stronę węgla i energetyki węglowej, a z drugiej źródło kosztownego programu modernizacji systemu energetycznego.

W strategii Unii Europejskiej pierwszeństwo mają technologie wytwarzania energii z odnawialnych źródeł energii (OZE) z wieloma realnymi ułatwieniami dającymi OZE nadzwyczajną rentę konkurencyjności w stosunku do energetyki konwencjonalnej. Wsparcie finansowe zarówno na etapie inwestycyjnym, jak i w trakcie bieżącego funkcjonowania, a także pierwszeństwo w odbiorze tej energii o niskiej jakości przez systemy dystrybucyjne obniża rentowność energetyki konwencjonalnej, której elektrownie węglowe de facto staja się „toksycznymi” biznesami. Co więcej, energetykę konwencjonalną obciąża handel $\mathrm{CO}_{2}$, którego wpływ na koszty energii po 2020 roku będzie systematycznie rósł. Rozwój OZE, handel $\mathrm{CO}_{2} \mathrm{w}$ powiazaniu z giełdowym obrotem energią elektryczną na rynkach hurtowych w Europie zwiększa niepewność i ryzyko ekonomiczne oraz destabilizuje bodźce do inwestycji w energetyce konwencjonalnej. Mimo to, nie można oczekiwać, że model niemieckiej Energiewende okaże się zawodny. Wręcz przeciwnie, energetyka zdecentralizowana i prosumencka, oparta na OZE, staje się wzorcem do naśladowania.

\section{Konsekwencje polityki klimatyczno-energetycznej dla Polski}

Realizacja przez Polskę zasad rozwoju zrównoważonego opartego na trwałości klimatycznej przyniesie zarówno pozytywne skutki, jak i negatywne. Przeprowadzenie gospodarki i społeczeństwa w obecnej perspektywie finansowej Unii Europejskiej nie wydaje się szczególnie problematyczne. Kluczowe bariery pojawią się po 2020 roku. Niewatpliwie, znacznie łatwiej będzie spełnić większość kryteriów społecznych i gospodarczych (miękkich) niż kryteriów klimatycznych i emisyjnych (twardych). Te pierwsze są łatwiejsze, ze względu na akceptowalność społeczną oraz polityczną atrakcyjność dla władz publicznych. Ponadto, nie są one podstawą wymiaru wygórowanych kar za brak wywiązania się z obowiązku.

Pakiet zimowy ostatecznie zamyka dyskusję o konieczności redukcji $\mathrm{CO}_{2}$ i dekarbonizacji. Jednocześnie wyznacza on kierunki modernizacji i unowocześnienia polskiej energetyki oraz gospodarki energetycznej w: przemyśle, budownictwie, transporcie, gospodarce komunalnej i w sektorze gospodarstw domowych. 
Polityka klimatyczno-energetyczna Unii Europejskiej per saldo jest obiektywnie trudna dla polskiej gospodarki z wielu względów, ponieważ będzie prowadzić do:

- wzrostu kosztów i cen energii;

- budowy bloków gazowych oraz przyspieszonej gazyfikacji i wzrostu uzależnienia gazowego;

- $\quad$ wymuszonej budowy drogiej energetyki jądrowej;

- utraty konkurencyjności: przemysłu, budownictwa, transportu i rolnictwa. Co więcej, niewykluczone, że zajdzie konieczność importu trzeciego nośnika - energii elektrycznej. Zgodnie z sugestiami płynącymi z Unii Europejskiej, deficyt z tytułu zamykania bloków węglowych Polska powinna ostatecznie uzupełniać importem z Unii [Polska powinna..., 2016].

Dodatkowy problem wobec polskiej energetyki stwarzają nowe regulacje Unii Eurpejskiej oparte na najlepszych, dostępnych technikach (BAT), a zaostrzające limity emisji: tlenków azotu, tlenków siarki i pyłów zawieszonych, dotychczas regulowane dyrektywą o emisjach przemysłowych dotyczących źródeł powyżej 50 MW oraz wprowadzające limity na związki chloru i metali ciężkich. Ważne, że te nowe regulacje obejmą nie tylko duże źródła emisji, lecz także źródła średniej wielkości (1-50 MW). Ich wdrożenie wymaga wysokich kosztów dostosowania źródeł energetyki zawodowej i przemysłowej oraz ciepłownictwa. Okresy przejściowe nieco złagodzą i rozłożą w czasie potrzeby finansowe.

Bilans energetyczny z przeważającym udziałem węgla stanowi poważne ograniczenie możliwości realizacji restrykcyjnej polityki klimatyczno-energetycznej Unii Europejskiej i wspierania rozwoju zrównoważonego w europejskim rozumieniu. Nie licząc niepewności i ryzyka związanego z uwarunkowaniami geopolitycznymi, niezbędna dywersyfikacja bilansu energetycznego jest obciążona znacznymi wydatkami na import gazu ziemnego i ropy naftowej, na których wyraźny wzrost Polska nie może sobie pozwolić. Struktura bilansu i geopolityka zdecydowanie wyróżniają Polskę na tle państw członkowskich. To prowadzi do systematycznego i trudnego do przełamania konfliktu Polski z Unią Europejska.

Czas na walkę o odrębne potraktowanie w Unii Europejskiej praktycznie skończył się, a osamotniona Polska niewiele już może zdziałać na arenie Unii Europejskiej, aby uzyskać złagodzenie wymogów i zmniejszyć obciążenie gospodarki i społeczeństwa. Ważniejsze batalie wokół polityki klimatyczno-energetycznej Polska przegrała. Do rozstrzygnięcia pozostają rozmiary rekompensaty i liczba darmowych uprawnień $\mathrm{CO}_{2}$, jaką otrzyma polska gospodarka. Norma do $550 \mathrm{~kg} \mathrm{CO} / \mathrm{MWh}$ w rzeczywistości eliminuje wegiel jako paliwo w blokach energetycznych, ponieważ nawet najnowocześniejsze bloki węglowe o parametrach nadkrytycznych nie moga zejść poniżej $750 \mathrm{~kg} \mathrm{CO} / \mathrm{MWh}$, a bloki super-nadkrytyczne poniżej $720 \mathrm{kgCO}_{2} / \mathrm{MWh}$. W tym kontekście perspektywy energetyki węglowej rysują się w ciemnych barwach. Po 2020 roku przyspieszy likwidacja górnictwa, a elektroenergetyka węglowa i sektor ciepłowniczy odczują głębokie zaburzenia funkcjonowania. Wypychanie węgla rodzi także problemy społeczno-polityczne. Najważniejszym wpływem w zakresie gospodarstw domowych będzie rozszerzanie się sfery ubóstwa energetycznego. De facto już obecnie połowa polskich go- 
spodarstw domowych znajduje się w sferze ubóstwa energetycznego, według kryteriów państw członkowskich Unii Europejskiej, znacznie bogatszych niż Polska, ponieważ średnie wydatki na: opał, paliwo i energię od co najmniej 12 lat przekraczają 10-procentowy udział w budżetach domowych [Budżety..., 2015, tabela 2.]. Należy również mieć na uwadze to, że obciążenia gospodarstw domowych z tytułu kosztów modernizacji energetyki zostaną powiększone przez uwolnienie cen energii eklektycznej i gazu.

Polska musi podjąć wyzwania klimatyczne i emisyjne na polu: organizacyjnym, prawnym, zarządczym i przede wszystkim technologicznym, aby dostosować się do wymagań Unii Europejskiej. Nie ma możliwości lekceważenia tego, co dzieje się w europejskiej energetyce. Konsekwentny opór byłby zgubną strategia o wysokim stopniu ryzyka. Im wcześniej i bardziej kompleksowo te wyzwania zostana podjęte, tym więcej czasu będzie na ich realizację. Poza warunkami organizacyjno-prawnymi, ekonomiczno-finansowymi i technicznymi oraz skutecznym monitoringiem, pozostaje kwestia świadomości społecznej i właściwych zachowań, zwłaszcza w zakresie niskiej emisji generowanej przez gospodarstwa domowe w zabudowie rozproszonej. Zakładając, że problemy: organizacyjno-prawne, regulacyjne i finansowe są w miarę potrzeb i możliwości realizowane, podstawowym uwarunkowaniem rozwoju gospodarki niskoemisyjnej są zmiany strukturalne i czynniki techniczne (innowacyjność i postęp techniczny). Pokonanie barier technicznych rozwoju gospodarki niskoemisyjnej wymaga bezwzględnego ukierunkowania polskich start-upów i innowacji na szeroko rozumianą energetykę, transport i inteligentne miasta, ekologiczne gminy czy gminy o obiegu zamkniętym. Szczególną rolę w zakresie innowacji muszą przyjać na siebie przedsiębiorstwa energetyczne oraz branże: przemysłu, budownictwa i transportu powiązane z energetyką lub energochłonne. Gospodarka niskoemisyjna to jednocześnie wielkie wyzwanie i wiele trudnych zadań dla samorządów terytorialnych. Europejska i światowa rewolucja energetyczna nie daje szans przedsiębiorstwom energetycznym, przemysłowi i samorządom na przeżycie w dotychczasowym stanie. Konieczna jest ucieczka do przodu - zmiana technologiczna o dużej głębokości i skierowanie energetyki w stronę ścieżki innowacyjnej.

W warunkach polskich nie można postępu technicznego ograniczyć do „ugazowienia" energetyki, OZE i poprawy efektywności energetycznej, lecz także uwzględnić przyjazne środowisku wykorzystanie węgla w krótkiej i średniej perspektywie. Polska Energiewende nie powinna pomijać technologii, które traktują węgiel jako surowiec energetyczny. Różne są oczekiwania wobec technicznych metod dochodzenia do gospodarki niskoemisyjnej, a zarazem różny jest ich stopień zaawansowania technologicznego.

\section{Kierunki zmian w elektroenergetyce}

Dekarbonizacja i gospodarka niskoemisyjna w elektroenergetyce obejmuje: odchodzenie od spalania węgla na rzecz gazu ziemnego, wytwarzanie energii elektrycznej z OZE, technologie redukcji $\mathrm{CO}_{2}$ oraz poprawę efektywności energetycznej wytwarzania i dystrybucji energii. 
Perspektywicznie OZE stanowią kluczowy czynnik rozwoju zarówno elektroenergetyki, jak i ciepłownictwa oraz ogrzewnictwa. Paradygmat energetyki rozproszonej w zasadzie jest już kwestią przesądzona, mimo obecnie jeszcze wysokich kosztów społecznych promocji OZE. Po stronie wytwórczej technologie energetyki wiatrowej i słonecznej osiagnęły wysoki stan dojrzałości technicznej i jednocześnie zajęły znaczącą pozycję w wytwarzaniu energii elektrycznej, tak że nie istnieją zagrożenia ich pozycji w przyszłości. OZE będa w stanie wytwarzać energię. $\mathrm{Na}$ obecnym etapie wobec OZE powstają tylko pytania, jaki ma być zakres ich wykorzystania i jakie będą koszty wytworzonej przez nie energii oraz jakie miejsce ma zając mikroenergetyka (prosumeryzm). Odpowiedzi na te pytania zależą od uwarunkowań regulacyjnych, przede wszystkim w zakresie i sposobie wparcia finansowego energii odnawialnej.

$\mathrm{Na}$ aktualnym etapie rozwoju technologii OZE nie stanowią samodzielnego źródła energii elektrycznej, ponieważ wymagają mocy rezerwowych w źródłach konwencjonalnych i magazynach energii elektrycznej. Przyszłość OZE i uniezależnienie od energetyki konwencjonalnej wiąże się z pojemnymi i ekonomicznie dostępnymi magazynami energii elektrycznej, zarówno systemowymi, jak i małymi, determinującymi rozwój energetyki rozproszonej, w tym energetyki prosumenckiej.

W warunkach generacji rozproszonej zarządzanie sieciami dystrybucyjnymi staje się bardzo złożone i w dużym stopniu zdecentralizowane, ponieważ sieć musi przejąć nowe funkcje, m.in. ważną dla stabilizacji sieci optymalizację lokalną przepływów sieciowych (smart grid) w warunkach zwielokrotnionych źródeł energii. Bez smart grid nie jest możliwa transformacja energetyki i budowa energetyki zdecentralizowanej. Brak sieci inteligentnych oznacza także zamknięcie dużej części potencjału innowacyjnego w dziedzinie energetyki. Zmienia się równocześnie rola wytwórców-odbiorców (prosumentów), którzy powinni również wziąć na siebie odpowiedzialność za pewne obowiązki, a nie tylko korzyści. Jednocześnie barierą rozwoju zdecentralizowanego wytwarzania energii elektrycznej z OZE jest obecnie jeszcze słaby stan techniczny sieci dystrybucyjnych i niewielkie moce przyłączeniowe sieci. Przede wszystkim dotyczy to sieci dystrybucyjnych poza terenami aglomeracji i dużych miast, a więc obszarów szczególnie korzystnych pod względem lokalizacji rozproszonych źródeł energetyki: wiatrowej, słonecznej i biomasowej. Aglomeracje miejskie z rozwiniętą siecią dystrybucyjną nie przedstawiają dużego potencjału w zakresie energetyki odnawialnej, ze względu na: ograniczenia terenowe, niewielką wietrzność i obniżone naświetlenie [eżowski, 2015, s. 18].

Aktualnie w Polsce wielkie nadzieje wiąże się z energia geotermalną. Dotychczasowe doświadczenia nie napawaja zbytnim optymizmem - sa projekty udane i projekty, które zawiodły. Generalnie, jest to energia czysta, ale droga i niskiej jakości termodynamicznej.

Technologie wychwytywania i magazynowania $\mathrm{CO}_{2}$ (CCS) w dalszym ciagu znajdują się in statu nascendi. Tu - w przeciwieństwie do instalacji OZE - nie ma spadku kosztów instalacji w czasie. Technologie CCS średniookresowo nie mają żadnego znaczenia praktycznego, co oznacza, że koncepcja CCS zawiodła. Perspektywiczne szanse w zakresie redukcji $\mathrm{CO}_{2} \mathrm{w}$ blokach energetycznych można łączyć ze spalaniem węgla 
w pętlach chemicznych (skuteczność redukcji $\mathrm{CO}_{2}$, stabilność procesu spalania i zachowanie sprawności bloków). Jednak technologia ta jeszcze nie przeszła fazy demonstracyjnej, co oddala fazę wdrożeniową [Rakowski, Bocian, Celińska, 2016].

Przesądzonym benchmarkiem rozwoju nowych mocy w energetyce kondensacyjnej są bloki opalane gazem ziemnym, w szczególności nowoczesne i wysoko sprawne bloki gazowo-parowe (60\%). Bloki gazowe pozwalają zmieścić się w normach emisji $\mathrm{CO}_{2}$ $i$ innych zanieczyszczeń powietrza. Nowoczesne bloki węglowe o parametrach nadkrytycznych wprawdzie pozwalają na podniesienie sprawności energetycznej do 45\% (co w porównaniu z istniejącymi blokami o sprawności 30-35\% jest znaczącym postępem), lecz nie są w stanie spełnić wymogów pakietu zimowego. Problem stanowią także ich wielkie rozmiary (850-1200 MW), długi czas budowy i wielkie ryzyko eksploatacyjne na wypadek awarii. Pewna szansa jest koncepcja budowy duobloków i biobloków pracujących w układzie z turbinami 50-500 MW o wyższej sprawności i większej elastyczności. Mogłyby one przyczynić się do rewitalizacji bloków 200 MW i uelastycznić strukturę mocy, która będzie coraz bardziej potrzebna w miarę rozwoju niestabilnych źródeł OZE i zamykania starych bloków. Jednak w sytuacji wypierania generacji węglowej przez OZE zbyt szeroki program odbudowy starych i rozwoju nowych mocy w blokach węglowych, w celu zapewnienia bezpieczeństwa energetycznego, w rezultacie może doprowadzić do pojawienia się kosztów osieroconych [Mielczarski, 2017].

Przesądzony w pakiecie zimowym limit emisji $\mathrm{CO}_{2}$ wprawdzie Polska nie jest w stanie przyjać, ale oznacza to, że budowa lub modernizacja bloków węglowych nie uzyska w Unii Europejskiej wsparcia w postaci pomocy publicznej. Prawdopodobnie nie zaistnieje również możliwość prostego współspalania biomasy w tych blokach [Limit emisji..., 2017].

\section{Gospodarka niskoemisyjna w ciepłownictwie}

Społeczne postrzeganie problemów ciepłownictwa i ogrzewnictwa w Polsce jest daleko słabsze niż górnictwa, elektroenergetyki, OZE i efektywności energetycznej. Percepcja ta jest nieproporcjonalna do znaczenia ciepłownictwa i ogrzewnictwa w systemie energetycznym oraz wagi barier ich rozwoju. Zaspokojenie potrzeb cieplnych budownictwa mieszkaniowego w miastach i na wsi nie może być traktowane marginesowo, nie tylko ze względu na zapewnienie komfortu cieplnego w strefie klimatycznej Polski, lecz także ze względu na to, że opał i energia cieplna kształtują cztery piąte łącznych wydatków budżetów domowych na energię. Ceny ciepła i opału bardziej poruszają opinię społeczną niż nagłaśniane ceny energii elektrycznej. Ponadto, ciepło, w przeciwieństwie do energii elektrycznej, nie jest usługą możliwą do importowania, ponieważ może być wytwarzane i użytkowane tylko in situ w przestrzeni ograniczonej do systemów sieci ciepłowniczej [Jeżowski, 2016, s. 11-12].

Rozwój ciepłownictwa jest zgodny z wymogami rozwoju zrównoważonego i wnosi wkład w gospodarkę niskoemisyjną przez: poprawę efektywności energetycznej, ograniczenie emisji gazów i pyłów do atmosfery (w tym również $\mathrm{CO}_{2}$ ) oraz potencjalną 
substytucję niskiej emisji. Presja ekologiczna zarówno gospodarki rozdzielonej (ciepłownie), jak i przede wszystkim gospodarki skojarzonej (elektrociepłownie) jest zdecydowanie mniejsza niż presja ogrzewnictwa indywidualnego (piece węglowe) i małych źródeł ciepła, takich jak lokalne kotłownie. W szczególności gospodarka skojarzona (kogeneracja) daje oszczędność około jednej czwartej paliwa na wytworzenie tej samej ilości energii finalnej, co przekłada się na rozmiary emisji zanieczyszczeń.

Problemem ciepłownictwa na najbliższe lata jest system wsparcia kogeneracji. Od dawna wiadomo, że w 2018 roku skończy się obowiązywanie systemu wsparcia źródeł kogeneracyjnych przez żółte i czerwone certyfikaty. Pomimo prac i uzgodnień prowadzonych od 2015 roku, dopiero jesienią 2018 roku zdecydowano się na mieszany system wsparcia - aukcje i stałe premie. Oczekuje on na notyfikację przez Komisję Europejska.

Głęboka restrukturyzacja źródeł ciepła wymaga zwiększenia zużycia gazu ziemnego, który jako paliwo benchmarkowe zapewnia umiarkowaną emisję $\mathrm{CO}_{2}$, a w konsekwencji pozwala na spełnienie wymogów emisyjnych. Wzrost zużycia gazu w ciepłownictwie i ogrzewnictwie to kluczowy czynnik gospodarki niskoemisyjnej, który zarazem służy rozwiązaniu problemu zanieczyszczenia powietrza. Stąd też wszystko to, co wiąże się z: niwelacją niepewności dostaw gazu ziemnego, pojemnością systemową magazynów gazu i poziomem cen, musi być przedmiotem szczególnej troski władz publicznych. Obecnie sektor ciepłowniczy intensywnie inwestuje w bloki gazowe i gazowo-parowe.

Niezmiernie ważną kwestią są dostawy gazu dla małych i średnich ciepłowni komunalnych, które ze względu na wymogi dyrektywy o emisjach przemysłowych źrodeł 1-50 MW muszą zostać zamknięte i zastąpione nie tyle modernizowanymi kotłami węglowymi, co nowoczesnymi kotłami gazowymi. Tam bowiem inne technologie niskowęglowe nie mają szans na wdrożenie.

Ciepłownictwo, obok kogeneracji, powinno już dziś nastawiać się na trigenerację (energia elektryczna, ciepło, chłód), a w dalszej perspektywie na polygenerację obejmującą dodatkowo m.in.: kompresję powietrza, biogaz, biometanol i gazy techniczne. Ciepłownictwo musi także wyjść poza dotychczasowy zakres działalności i postawić na wielopaliwowość, w tym zwłaszcza na wykorzystanie: biomasy lokalnego pochodzenia, odpadów i energii słonecznej oraz budowę magazynów ciepła celem zagospodarowania nadmiarowej energii systemowej i słonecznej. Lokalne źródła ciepła i systemy sieciowe muszą zmierzać w takim kierunku jak elektroenergetyka, czyli osiagać większą elastyczność, która intensyfikuje mobilność związaną ze zmianami w otoczeniu wewnętrznym i zewnętrznym. Przedsiębiorstwa ciepłownicze powinny wdrażać nie tylko nowe technologie ciepłownicze (kogeneracja, magazyny energii, wykorzystanie OZE), lecz również świadczyć dodatkowe usługi, w tym usługi zarządzania energią. Ciepłownictwo nie może kurczowo trzymać się monopolu naturalnego. Zmiana profilu działalności przedsiębiorstw, podobnie jak w elektroenergetyce, jest nieunikniona i jednocześnie wskazana.

Sektor ciepłowniczy powinien zarazem aktywniej włączyć się w rozwiązywanie kwestii niskiej emisji, to jest substytucji zaopatrzenia indywidualnego w zbiorowe, traktując to jako naturalne zadanie, oraz wymiany pieców węglowych na ekologiczne, wychodząc 
poza dotychczasowy obszar działania. Substytucja indywidualnego ogrzewania węglowego przez zaopatrzenie sieciowe w miastach w zabudowie zwartej i słabo rozproszonej musi być uznana za jeden z priorytetów sektora ciepłowniczego. Kwestią otwartą pozostaje równocześnie ciepłownictwo punktowe (niesystemowe), gdzie firmy zasiedziałe mogą dostarczać usługi know-how w zakresie budowy różnopaliwowych małych elektrociepłowni i wyspowych sieci cieplnych z elementami automatyki hydraulicznej i temperaturowej, w części przyczyniając się do promowania rozwoju biogospodarki czy też gospodarki zamkniętej.

\section{Ograniczony potencjał konwersji odpadów i węgla}

W gospodarce komunalnej, poza ciepłownictwem, pewien potencjał gospodarki niskoemisyjnej przedstawia termiczne wykorzystanie zmieszanych odpadów komunalnych. Stan rozwoju tych technologii przede wszystkim wskazuje na znaczenie spalania odpadów. Technologie spalania są dojrzałe, sprawdzone i ciagle doskonalone. Wymogiem procesu spalania jest skuteczne oczyszczanie spalin i ścieków oraz zagospodarowanie frakcji odpadowych. Poza korzyściami dla gospodarki odpadami (redukcja masy deponowanych odpadów, odzysk surowców i materiałów), następstwem spalania odpadów jest oszczędność paliwa potrzebnego do wytworzenia energii elektrycznej i ciepła. Słabą strona jest kwestia społecznej akceptacji dotyczącej lokalizacji tego rodzaju instalacji oraz logistyka i dowóz odpadów. Spalarnie to urządzenia kapitałochłonne, więc kluczową kwestią sa gwarancje dopływu odpadów do przetworzenia, aby zapewnić wysoki i stabilny stopień obciążenia kotłów. Warunki te przesądzają o efektywności ekonomicznej przetwarzania termicznego. Potencjał redukcji $\mathrm{CO}_{2}$ przez te technologie jest w Polsce częściowo wykorzystany. Uznawane za postępowe procesy pirolizy i zgazowania odpadów nie przedstawiają na razie technologii dojrzałych, mimo szerokiego ich marketingu i licznych zwolenników. Miasta, które decydują się na pirolizę lub zgazowanie odpadów komunalnych, podejmują duże ryzyko.

W istniejących uwarunkowaniach energetyki konieczne byłoby wykorzystanie rozwiązań technicznych związanych z konwersją węgla, głównie na paliwa gazowe i stałe. Jednak wszystkie metody konwersji węgla na paliwa gazowe, płynne i stałe są kosztowne ze względu na straty przemian energetycznych, a efektywność ekonomiczna konwersji zależy od: typu przemian, jakości wsadu surowcowego i skali produkcji substratów węglowych. W rezultacie konwersja węgla nie otwiera perspektyw o istotnym znaczeniu bilansowym.

Jedną z możliwości konwersji węgla wielkiej skali jest podziemne zgazowanie węgla bezpośrednio w złożach, generalnie o gorszej lokalizacji i niskiej wartości eksploatacyjnej. Atrakcyjność podziemnego zgazowania jest upatrywana w obejściu fazy wydobycia i transportu węgla. Ta technologia znana jest od ponad pół wieku, lecz praktyka jej wykorzystania nie napawa optymizmem. Wytwarzanie gazu w procesie podziemnego zgazowania węgla - jak zauważyli P. Mocek i K. Stańczyk - nie osiagnęło jeszcze pełnej dojrzałości przemysłowej, a opanowanie tej technologii wymaga dalszych prac badawczych. Podziemne zgazowanie węgla jest trudną metodą konwersji węgla, co 
zwłaszcza wynika z ryzyka skażenia środowiska i problemu kontroli procesu zgazowania. Ponadto, podstawowym produktem procesu zgazowania jest zanieczyszczony gaz o niskiej wartości opałowej [Mocek, Stańczyk, 2016]. Badania i projekty pilotażowe w tym zakresie niewiele wniosą do rozwiązań przetestowanych negatywnie już w ubiegłym wieku.

Bardziej realistyczne jest naziemne zgazowanie węgla. Produktem procesu zgazowania w procesach półspalania jest gaz średniej wartości opałowej oraz inne produkty karbochemiczne, w tym metanol. Jest to technologia historyczna, dobrze znana z ponad stuletniej praktyki w USA i Europie w postaci gazowni miejskich i obecnie funkcjonujących na świecie zakładów produkcji amoniaku i metanolu dla przemysłu chemicznego [Ciepiela, 2015]. Technologie zgazowania węgla w II połowie XX wieku zostały z przyczyn ekonomicznych wyparte przez gaz ziemny. Obecnie sa rozwijane przede wszystkim w Azji (w Chinach, Indiach, Japonii) zarówno dzięki budowie wielkich reaktorów węglowych, jak i mniejszych instalacji na biomasę. Osłabienie zainteresowania nimi w USA jest pokłosiem nadziei pokładanych w gazie łupkowym [Hałgas, 2016]. Pozyskany ta droga gaz mógłby być bezpośrednio in situ wykorzystany w elektrociepłowniach i elektrowniach oraz w przemyśle chemicznym, ponieważ jako gaz niewymienny z gazem ziemnym nie nadaje się do wtłoczenia do sieci gazowej. Jednak należy być świadomym, że są to technologie kapitałochłonne i 2-3 razy droższe od rozwiązań węglowych. Stąd też nie ma istotnych przesłanek rozwoju wielu instalacji. Natomiast specjaliści w tej dziedzinie uważaja że głównym obszarem ekonomicznego wykorzystania syngazu jest przemysł chemiczny, a nie energetyka [Prof. Ściażko..., 2017].

\section{Ogrzewnictwo indywidualne}

Potrzeby w zakresie właściwego paliwa dla ogrzewnictwa i małych kotłowni w skali kraju są duże, ponieważ indywidualne ogrzewanie obejmuje 3,5 mln domów. W zasadniczej części jest to ogrzewanie węglowe. Skala ogrzewnictwa węglowego na wsi jest zdecydowanie większa niż w miastach. O ile Polska ma bardzo wysoki udział węgla w zużyciu końcowym energii (wskaźnik zacofania bilansu energetycznego), wynoszący jedna czwarta, to w gospodarstwach domowych jest on jeszcze wyższy (dwie piąte), z tym że na wsi ten udział wynosi aż trzy czwarte, a w mieście nieco ponad jedna piąta. Konsekwencją bezpośredniego zużycia węgla jest niska emisja i smog oraz to, że polskie miasta niechlubnie zajmują czołowe pozycje w rankingach najbardziej zanieczyszczonych w Europie. Problem niskiej emisji i zagrożenia smogiem jest znany od dawna, niemniej Polska niewiele dotychczas poczyniła w kierunku poprawy sytuacji $\mathrm{w}$ tym zakresie. Wcześniej wprowadzony zakaz spalania paliw niskiej jakości dałby bezpośrednie efekty redukcji niskiej emisji i byłby stałym bodźcem do ekspansji ogrzewnictwa gazowego i ciepła sieciowego. Racjonalnym wyjściem jest indywidualne ogrzewanie gazowe. Jednak nie wszędzie gaz może być dostarczony, a pelety i inne paliwa ekologiczne nie są w stanie wypełnić brakującej luki. Także ekspansja ciepłownictwa na obszary rozproszonej zabudowy miast ma swoje granice. Wsparciem ekologicznego ogrzewnic- 
twa indywidualnego może stać się paliwo błękitne (o parametrach zbliżonych do koksu) wytwarzane w procesie odgazowania węgla. Produkcja bezdymnego paliwa błękitnego na skalę przemysłową $z$ dostosowaniem sprawności pieców i małych kotłów może radykalnie ograniczyć niską emisję w zabudowie rozproszonej w miastach i na wsi.

W sytuacji szerokiego ogrzewnictwa indywidualnego, opartego na spalaniu węgla, nie wystarczy zakazać spalania węgla i sprzedaży pieców starszych generacji. Konsumenci niekorzystający z gazu muszą mieć realny wybór ekologicznego paliwa zastępczego i nabycia efektywnych energetycznie pieców po rozsądnej cenie, co jednak wymaga konkretnego wsparcia finansowego tak paliwa ekologicznego, jak i pieców najnowszych generacji.

Z ogrzewnictwem w szczególności wiąże się kwestia efektywności energetycznej budynków mieszkalnych. Technologie poprawy efektywności energetycznej są dawno rozpoznane. Potencjał oszczędności energii w budynkach mieszkalnych jest duży, gdyż tylko połowa mieszkań - według A. Stępniak - znajduje się w budynkach ocieplonych, z czego duża część wymaga ponownej termomodernizacji. Gorsza sytuacja dotyczy budownictwa jednorodzinnego, gdzie tylko co czwarty budynek zachowuje standardy techniczne [Stępniak, 2016]. Tempo termomodernizacji przede wszystkim ograniczaja koszty i zakres wsparcia finansowego

\section{Elektromobilność}

Koncepcja elektromobilności jest słusznym kierunkiem gospodarki niskoemisyjnej, aczkolwiek związane z nią oczekiwania są wygórowane. Nie wydaje się, że elektryczne pojazdy są także w stanie uratować polskie górnictwo węglowe i zapewnić elektroenergetyce węglowej znaczące przychody. Potencjał redukcji zanieczyszczeń powietrza przez pojazdy elektryczne jest w zasadzie ograniczony do przestrzeni miejskich. Tak naprawdę istotny postęp można osiagnąć w zakresie transportu publicznego. Natomiast promocja samochodu elektrycznego w użytkowaniu prywatnym, ze względu na koszty i zasobność społeczeństwa w Polsce, to dopiero dalsza przyszłość, która zależy od wsparcia użytkowników prywatnych. Innym problemem jest dostosowanie sieci dystrybucyjnej i infrastruktury ładującej pojazdy, gdyż pociaga to za sobą wydatki operatorów sieci, które z kolei wpływają na ceny energii elektrycznej i obciążają wszystkich jej odbiorców [Chojnacki, 2017]. Nieracjonalne jest preferowanie elektromobilności z pominięciem potencjału gazyfikacji pojazdów kołowych [Ustawa..., 2017]. Tylko skoordynowane przedsięwzięcia w zakresie: transportu szynowego, elektromobilności i gazomobilności oraz zarządzania ruchem mogą realnie przyczynić się do synergicznego obniżenia emisyjności transportu. Jednocześnie przedsięwzięcia mobilności powinny być wkomponowane w inne organizacyjne i technologiczne obszary całościowej koncepcji smart city i miast o gospodarce zamkniętej (circular economy). 


\section{Podsumowanie}

W polityce klimatyczno-energetycznej Unii Europejskiej, która stanowi fundament rozwoju zrównoważonego w europejskim rozumieniu, znajdują się elementy pozytywne związane ze zmniejszeniem presji na środowisko, mające wpływ na dobrobyt społeczny i zdrowie ludzi oraz na unowocześnienie energetyki i gospodarki, natomiast część zbyt ambitnych wytycznych ma charakter wątpliwy i jest niesprawiedliwa dla niektórych państw członkowskich. Racjonalnym kierunkiem rozwoju jest promocja OZE i efektywności energetycznej, a także ograniczanie emisji przemysłowych i niskiej emisji. Natomiast wielki nacisk na dekarbonizację wydaje się przedwczesny tak ze względów technologicznych, jak i politycznych (brak uzgodnień międzynarodowych). Prowadzi on bowiem do nieskuteczności ekologicznej i w pewnym zakresie szkodzi klimatowi przez migrację energochłonnego przemysłu poza granice Unii Europejskiej.

Polityka klimatyczno-energetyczna Unii Europejskiej w dużej mierze pozostaje w sprzeczności z możliwościami Polski i wewnętrznie postrzega się ją jako nie do końca sprawiedliwa, co powoduje, że Polska naraża się na systematyczny konflikt z Unią Europejską jako całością i z najważniejszymi jej członkami. W wielu wymiarach obiektywnie trudno Polsce zaakceptować taką politykę, ponieważ wymusza ona radykalną zmianę energetyczną, osłabia konkurencyjność polskiej gospodarki oraz stanowi trwały czynnik wzrostu cen energii finalnej i obciążeń budżetów domowych. Jednak nie wszystko można usprawiedliwić konsekwentną polityką Unii Europejskiej na zasadzie zewnętrznego umiejscowienia kontroli. W wielu kwestiach Polska ponosi odpowiedzialność za niską decyzyjność i opóźnianie przedsięwzięć oraz liczenie na skuteczność negocjacyjną własnej dyplomacji.

Konieczność aktywnego podejścia do transformacji polskiej energetyki w perspektywie 2030 roku i dalszej jest zadaniem wymagającym wysiłku: organizacyjnego, technologicznego i finansowego, tym bardziej że możliwości uzyskania przez Polskę specjalnego statusu praktycznie wyczerpały się po przegranych bataliach negocjacyjnych, a sprawy finansowania projektów inwestycyjnych przez Unię Europejską w okresie 2021-2030 są jeszcze niepewne. W świetle pakietu zimowego nowe bloki węglowe na pewno nie uzyskają wsparcia Unii Europejskiej. Polską energetykę czeka rewolucja technologiczna i ogromny, trudny do uniesienia, wielki program inwestycyjny okresu przejściowego - nieporównywalny z żadnym innym państwem członkowskim Unii Europejskiej. Przy wielopłaszczyznowych zapóźnieniach są potrzebne: rozwój, innowacje i modernizacja źródeł energii nie tylko wielkoskalowych, lecz także średniej, małej i mikroskali. Walka z emisją $\mathrm{CO}_{2}$ i konsekwentna dekarbonizacja w szczególny sposób odbija się na: polskim górnictwie, elektroenergetyce i ciepłownictwie.

Poza substytucją węgla z gazem ziemnym, szerszym wykorzystaniem OZE, poprawa efektywności energetycznej i gospodarką skojarzoną w ciepłownictwie, jak również w pewnym zakresie w gazo- i elektromobilności w transporcie oraz termicznym przekształcaniem odpadów komunalnych, nie ma wielu wydajnych i tanich rozwiązań technicznych, które by z jednej strony służyły ratowaniu klimatu i wiodły do gospodarki niskoemisyjnej, z drugiej zapewniały minimalne perspektywy węgla. Istotą transformacji polskiej energetyki jest wzrost roli gazu ziemnego w systemie energetycznym. Gaz 
ziemny to decydujący czynnik modernizacji: elektroenergetyki, ciepłownictwa i ogrzewnictwa indywidualnego. Techniczne możliwości redukcji $\mathrm{CO}_{2} \mathrm{w}$ procesach spalania i konwersji węgla są obecnie skromne. Technologiom CCS i podziemnego zgazowania węgla brakuje dojrzałości. Nie licząc substytucji węgla przez gaz i OZE, innowacje energetyczne powinny zmierzać w kierunku: zintegrowanego kojarzenia źródeł konwencjonalnych z OZE, rozwoju smart grid, magazynowania energii elektrycznej i cieplnej, produkcji paliwa błękitnego oraz w ograniczonym zakresie naziemnego zgazowania węgla. Ze względów bilansowych w Polsce nierealne jest daleko idące i szybkie zastapienie węgla gazem ziemnym oraz energia z OZE. Polska potrzebuje więcej czasu na spełnienie zobowiązań wobec Unii Europejskiej.

Przeprowadzenie modernizacji polskiej energetyki, zgodnej z europejskim rozumieniem rozwoju zrównoważonego, jest jednym z najważniejszych celów polityki publicznej. To, co Polska musi niezwłocznie wykonać w dziedzinie planowania, to przedstawić zintegrowany plan krajowy w zakresie klimatu i energii do akceptacji Unii Europejskiej. Jednocześnie potrzebne są odpowiedzialny dobór poziomu generacji rozproszonej oraz rozstrzygnięcie opłacalności i ostateczna decyzja w sprawie energetyki jądrowej. Uniknięcie błędów zarządzania wymaga doceniania technologicznych, regulacyjnych i politycznych sygnałów ostrzegawczych i ich znaczenia dla sektora energetycznego. Liczy się również jakość administracji publicznej i jej sprawność w tworzeniu na czas ram prawnych i regulacyjnych dla energetyki. W sytuacji kosztownej drogi do nowoczesnej energetyki jest zarazem ważne przekonanie społeczeństwa, że obecne poniesienie kosztów transformacji energetyki jest niezbędne, aby w przyszłości koszty te nie były jeszcze wyższe.

\section{Literatura}

A policy framework for climate and energy in the period from 2020 to 2030, 2014, European Commission, Brussels, 22.1.2014, COM(2014) 15 final.

Budizety gospodarstw domowych w 2014 r. - wybrane tabele z. danymi z. lat 2000-2014, 2015, GUS, http://stat.gov.pl/download/gfx/portalinformacyjny/pl/defaultaktualnosci/ 5486/9/9/1/budzety_gospodarstw_domowych_2014_-_tablice_przegladowe_ 2000-2014.xlsx, tabela 2. (data wejścia: 05.05.2017).

Chojnacki I., 2017, Ustawa o elektromobilności može nie wystarczyó do pobudzenia rynku, http://www.wnp.pl/wiadomosci/ustawa-o-elektromobilnosci-moze-nie-wystarczyc-do-pobudzenia-rynku,297505_1_0_1.html (data wejścia: 08.05.2017).

Ciepiela D., 2015, Zgazowanie wegla w du亡̌ej skali w Polsce jest realne, www.wnp.pl (data wejścia: 17.06.2015).

European Council (23 and 24 October 2014) - Conclusions, 2014, European Council, Brussels, 24 October 2014, EUCO 169/14.

Hałgas J., 2016, O procesie zgazowania wegla stón kilka..., „Wiadomości Naftowe i Gazownicze", nr 7-9.

Jeżowski P., 2013, Trwatość a rozwój zrónnowažony, „Studia KPZK PAN”, t. CLII. 
Jeżowski P., 2015, Przestrzenne aspekty rozwoju smart grid w Polsce. Raport z badan statutouych, Katedra Rozwoju Regionalnego i Przestrzennego Szkoły Głównej Handlowej, Warszawa.

Jeżowski P., 2016, Wkład cieptownictwa i ogrzennictwa do roz̧oju zrónnoważonego miast polskich. Raport z badan statutonych, Katedra Rozwoju Regionalnego i Przestrzennego Szkoły Głównej Handlowej, Warszawa.

Jeżowski P., 2017, O niektórych problemach gospodarki niskoemisyjnej, „Studia z Polityki Publicznej", nr 1 (13).

Limit emisji $\mathrm{CO}_{2}$ z.pakietu zimowego, nie do raakceptowania, 2017, http://www.cire.pl/ item,140237,1,0,0,0,0,0,naimski-limit-emisji-co2-z-pakietu-zimowego-nie-dozaakceptowania.html (data wejścia: 20.01.2017).

Mielczarski W., 2017, Pakiet Zimowy: szanse $i$ zagrożenia, http://www.cire.pl/item, 144357,13,1,2,0,307846,0,mielczarski-pakiet-zimowy-szanse-i-zagrozenia.html \#komentarz (data wejścia: 18.04.2017).

Mocek P., Stańczyk K., 2016, Analiza techniczno-ekonomiczna pilotowej elektrocieptowni zasilanej gazem PZW i weglem, „Energetyka”, nr 4.

Morawiecka M., 2017, Pakiet zimowy - çyysta energia dla wszystkich Europejçylkón çy raczej koniec krajonych polityle energetycznych?, http://www.cire.pl/item,145414,2,0,0,0, 0,0,pakiet-zimowy---czysta-energia-dla-wszystkich-europejczykow-czy-raczejkoniec-krajowych-polityk-energetycznych.html (data wejścia: 11.05.2017).

Polska powinna inwestować w OZE $i$ importować energie, 2016, http://www.cire.pl/item, 137836,1,0,0,0,0,0,niemcy-polska-powinna-inwestowac-w-oze-i-importowacenergie-html (data wejścia: 29.11.2016).

Prof. Ścià̇ko: rgazowanie wegla bardzo optacalne dla chemii, mniej dla energetyki, 2017, http://naukawpolsce.pap.pl/aktualnosci/news,414021,prof-sciazko-zgazowaniewegla-bardzo-oplacalne-dla-chemii-mniej-dla-energetyki.html (data wejścia: 02.05.2017).

Rakowski J., Bocian P., Celińska A., 2016, Zastosowanie petli chemicznych w energetyce, „Energetyka”, nr 4.

Stępniak A., Ciepto-zimnno, csylli o ubóstwie energetycznym, 2016, http://chronmyklimat.pl/ projekty/klimapolka/aktualnosci/cieplo-zimno-czyli-o-ubostwie-energetycznym (data wejścia: 28.09.2016).

Ustawa o elektromobilności uderyy w gminy. Co z. autobusami na gą?, 2017, http://www.portal samorzadowy.pl/gospodarka-komunalna/ustawa-o-elektromobilnosci-uderzy-wgminy-co-z-autobusami-na-gaz,93717.html (data wejścia: 24.05.2017). 